\title{
The Effect of Transition Metal Ions on the Resistance of Bacterial Spores to Hydrogen Peroxide and to Heat
}

\author{
By W. M. WAITES, CATHERINE E. BAYLISS, N. R. KING AND \\ A. M. C. DAVIES \\ Agricultural Research Council Food Research Institute, Colney Lane, \\ Norwich NR4 $7 U A$
}

(Received 23 October 1978)

\begin{abstract}
The presence of $10 \mu \mathrm{M}-\mathrm{Cu}^{2+}$ increased the lethal effect of hydrogen peroxide on spores of Clostridium bifermentans but not on those of Clostridium sporogenes PA 3679, Clostridium perfringens, Bacillus cereus or Bacillus subtilis var. niger. $\mathrm{Cu}^{2+}$ at $100 \mu \mathrm{M}$ also increased the lethal effect of heat on spores of $C$. bifermentans but not on those of $B$. subtilis var. niger. The rate and extent of $\mathrm{Cu}^{2+}$ uptake by spores of $C$. bifermentans and $B$. subtilis var. niger were similar, but examination of unstained sections of spores by electron microscopy suggested that $\mathrm{Cu}^{2+}$ is bound by the protoplasts of spores of $C$. bifermentans but not of $B$. subtilis var. niger.
\end{abstract}

\section{INTRODUCTION}

Transition metal ions inhibit the germination of bacterial spores (Levinson \& Sevag, 1953; Krishna Murty \& Halvorson, 1957; Murakami, 1971). We have shown previously that addition of $10 \mu \mathrm{M}-\mathrm{Cu}^{2+}$ caused a fivefold increase in the lethal effect of $\mathrm{H}_{2} \mathrm{O}_{2}$ on spores of Clostridium bifermentans and that addition of other divalent metal ions also slightly increased the kill (Bayliss \& Waites, 1976). Preliminary results suggested that such ions do not markedly increase the effect of $\mathrm{H}_{2} \mathrm{O}_{2}$ on spores of other species. This paper reports a more detailed study of the influence of metal ions on the resistance of spores of several species to $\mathrm{H}_{2} \mathrm{O}_{2}$ and to heat.

\section{METHODS}

Organisms, spore preparation and maintenance of cultures. The strains of Clostridium bifermentans, Bacillus cereus and Bacillus subtilis var. niger used and the methods of spore preparation were those described previously (Bayliss \& Waites, 1976; Wyatt \& Waites, 1975). Clostridium sporogenes PA 3679 and Clostridium perfringens NCTC 8238 were obtained from Dr G. C. Mead of this laboratory. Spores of C. sporogenes PA 3679 were prepared by growth at $33{ }^{\circ} \mathrm{C}$ under $\mathrm{H}_{2} / \mathrm{CO}_{2}(9: 1, \mathrm{v} / \mathrm{v})$ for $3 \mathrm{~d}$ on a medium containing $\left(\mathrm{g}^{-1}\right)$ : skim milk powder (Oxoid), 50; yeast extract (Difco), 3 ; peptone (Oxoid), 5; trypticase (BBL), $5 ; \mathrm{MnCl}_{2}$. $4 \mathrm{H}_{2} \mathrm{O}, 0.072$; cysteine hydrochloride (BDH), 0.5; agar (Davis), 15; adjusted to a final $\mathrm{pH}$ of 7.0 to 7.2 with $1 \mathrm{M}-\mathrm{NaOH}$. Spores of $C$. perfringens were prepared by growth at $33^{\circ} \mathrm{C}$ for $48 \mathrm{~h}$ in the medium of $\mathrm{Kim}$ et al. (1967). Spores were washed five times with glass-distilled water at $4{ }^{\circ} \mathrm{C}$ before storing in glass-distilled water; those of $B$. cereus were stored at $-20^{\circ} \mathrm{C}$ and the remainder at $1{ }^{\circ} \mathrm{C}$. The anaerobes were maintained in Robertson's cooked meat medium (double quantity meat, Southern Group Laboratories) and the aerobes on heart infusion agar (Difco).

Treatment of spores with metal ions, hydrogen peroxide, heat and urea/mercaptoethanol. Spores were treated at about $0.7 \mathrm{mg}$ dry wt $\mathrm{ml}^{-1}$. Unless otherwise stated, metal ions were pre-incubated with spores for $30 \mathrm{~min}$ at $37^{\circ} \mathrm{C}$. In some experiments the spores were then washed twice by centrifugation with glassdistilled water at $4{ }^{\circ} \mathrm{C}$, but essentially the same results were achieved with or without washing.

Hydrogen peroxide (Analar grade, $\mathrm{BDH}$ ) at the required concentration was added to spores in $100 \mathrm{~mm}$ sodium phosphate buffer $\mathrm{pH} 7.0 \mathrm{which}$ had been pre-incubated at the required temperature in polypropylene 


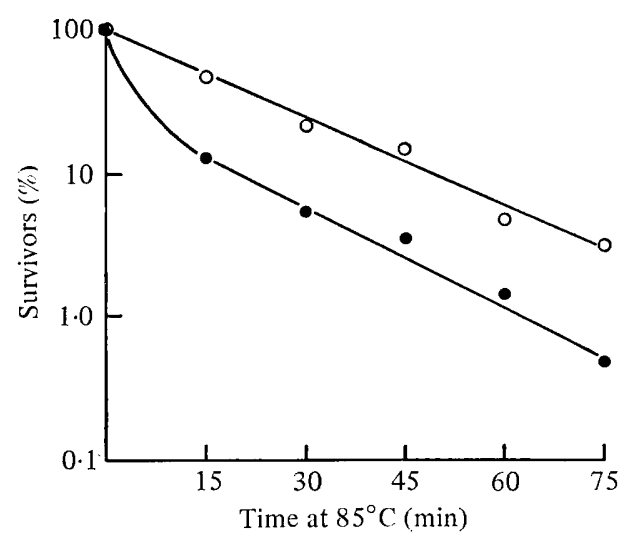

Fig. 1. Effect of heat and $\mathrm{Cu}^{2+}$ on the colony-forming ability of spores of C. bifermentans. Spores were incubated with $(O)$ or without $(O) 100 \mu \mathrm{M}-\mathrm{Cu}^{2+}$ for $30 \mathrm{~min}$ at $37^{\circ} \mathrm{C}$ before centrifugation and washing as described in Methods. After resuspension in glass-distilled water, the spores were heated at $85^{\circ} \mathrm{C}$ and samples were removed at intervals for dilution and plating.

centrifuge tubes. Spores were also heated in glass-distilled water alone. After incubation, the tubes were cooled rapidly to $1{ }^{\circ} \mathrm{C}$ and the contents were diluted immediately with glass-distilled water.

Spores were treated for $90 \mathrm{~min}$ at $37{ }^{\circ} \mathrm{C}$ with $4 \mathrm{M}$-urea in $10 \%(\mathrm{v} / \mathrm{v})$ mercaptoethanol, adjusted to $\mathrm{pH} 10 \cdot 3$ with $6 \mathrm{M}-\mathrm{NaOH}$. After treatment, the spores were cooled rapidly to $1{ }^{\circ} \mathrm{C}$, centrifuged for $10 \mathrm{~min}$ at $15000 \mathrm{~g}$ and $4{ }^{\circ} \mathrm{C}$, and washed twice by further centrifugation with glass-distilled water.

Colony formation, germination and outgrowth. Colony formation of B. cereus, B. subtilis and C. bifermentans was examined as described previously (Wyatt \& Waites, 1975). Clostridium sporogenes PA 3679 was plated on the reinforced clostridial medium of Hirsch \& Grinsted (1954) solidified with $1.6 \%$ (w/v) agar (Davis), and $C$. perfringens on the trypticase/yeast extract (TCYS) medium of Adams (1973). Germination of $C$. bifermentans was measured spectrophotometrically with the 'Ala +' germination system (Bayliss \& Waites, 1976) as described by Waites \& Wyatt (1971) or, after treatment with urea/mercaptoethanol, with lysozyme (Wyatt \& Waites, 1974) by counting 100 spores using a phase-contrast microscope and scoring dark (germinated) and bright (ungerminated) spores. Outgrowth of $C$. bifermentans was studied at $37^{\circ} \mathrm{C}$ in medium containing casein hydrolysate flushed with $\mathrm{H}_{2} / \mathrm{CO}_{2}(9: 1, \mathrm{v} / \mathrm{v})$ as described by Waites \& Wyatt (1974).

Turbidity and spore dry weight. Samples were removed during outgrowth and their turbidity was measured at $600 \mathrm{~nm}\left(A_{600}\right)$. Dry weights were estimated by converting absorbance to spore dry weight using a standard calibration curve.

Measurement of $\mathrm{Cu}^{2+}$ in spores by atomic absorption spectroscopy. Spore suspensions were digested in $6 \mathrm{M}-\mathrm{HCl}$ and diluted for analysis. The copper content was determined using a Varian AA6 spectrophotometer with an oxidizing air/acetylene flame. Conditions used were a wavelength of $324 \cdot 7 \mathrm{~nm}$, a slit width of $0.5 \mathrm{~nm}$, and a lamp current of 5.0 mA. Concentrations were determined from a calibration curve obtained with standard solutions of $\mathrm{CuCl}_{2}(\mathrm{BDH}$, for atomic absorption spectroscopy).

Preparation of samples for electron microscopy. Spore suspensions were fixed with buffered $3 \%(\mathrm{v} / \mathrm{v})$ glutaraldehyde for $3 \mathrm{~h}$ (without any subsequent fixation with osmium tetroxide) before washing overnight in buffer (Gordon et al., 1963). Samples were then dehydrated and embedded, and sections were examined with or without staining with uranyl acetate and lead acetate as described previously (Waites et al., 1972).

\section{RESULTS}

\section{Effect of metal ions on the resistance of spores to hydrogen peroxide and to heat}

The presence of $10 \mu \mathrm{M}-\mathrm{Cu}^{2+}$ during treatment of spores of $C$. sporogenes PA 3679, $C$. perfringens, $B$. subtilis or $B$. cereus with $\mathrm{H}_{2} \mathrm{O}_{2}$ failed to increase the lethal effect and even at $100 \mu \mathrm{M}, \mathrm{Cu}^{2+}, \mathrm{Co}^{2+}, \mathrm{Zn}^{2+}, \mathrm{Fe}^{2+}, \mathrm{Ni}^{2+}, \mathrm{Mn}^{2+}, \mathrm{Mg}^{2+}$ or $\mathrm{Ca}^{2+}$ did not increase the kill of spores of $B$. subtilis.

Divalent metal ions such as $\mathrm{Cu}^{2+}$ increase the hydrolysis of peptides at $75^{\circ} \mathrm{C}$ (Hill, 1965) suggesting that they might also decrease the heat resistance of spores. The colony-forming ability of spores of $C$. bifermentans was reduced substantially during heating at $85^{\circ} \mathrm{C}$ after 

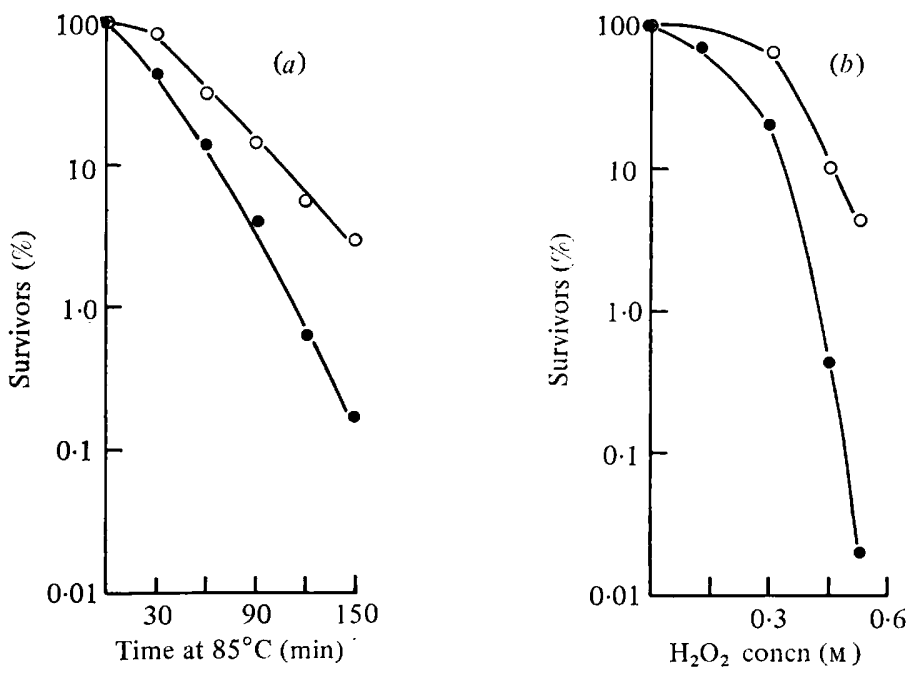

Fig. 2. Effect of heat or $\mathrm{H}_{2} \mathrm{O}_{2}$ on the colony-forming ability of spores of C. bifermentans grown in the presence or absence of $100 \mu \mathrm{M}-\mathrm{CuSO}_{4}$. Spores grown in the presence $(O)$ or absence $(O)$ of $100 \mu \mathrm{M}-\mathrm{CuSO}_{4}$ were $(a)$ heated at $85^{\circ} \mathrm{C}$ or $(b)$ incubated at $25^{\circ} \mathrm{C}$ with $\mathrm{H}_{2} \mathrm{O}_{2}$, before dilution and plating as described in Methods.

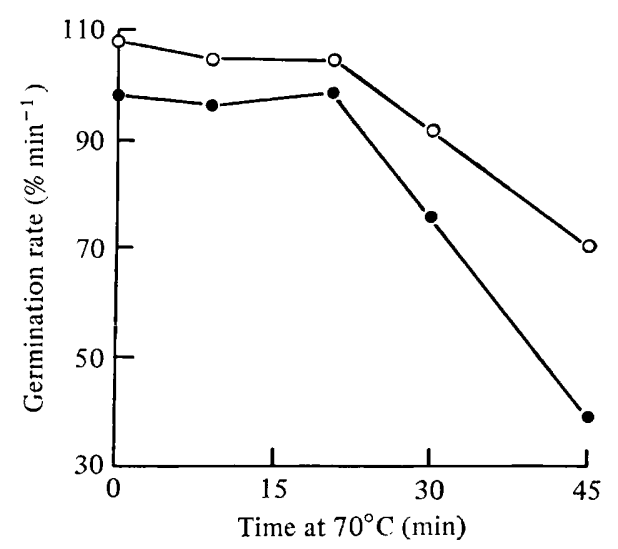

Fig. 3. Effect of heat and $\mathrm{Cu}^{2+}$ on the germination rate of spores of $C$. bifermentans. Spores were incubated with $(\circlearrowleft)$ or without $(O) 10 \mu \mathrm{M}-\mathrm{Cu}^{2+}$ for $30 \mathrm{~min}$ at $37^{\circ} \mathrm{C}$ before washing and heating at $70^{\circ} \mathrm{C}$. Samples were removed at intervals and their germination rate with the 'Ala+' system was determined spectrophotometrically.

pre-incubation in $100 \mu \mathrm{M}-\mathrm{Cu}^{2+}$ (for example, about sixfold after heating for $75 \mathrm{~min}$; Fig. 1). Addition of $100 \mu \mathrm{M}-\mathrm{Cu}^{2+}$ to the medium on which spores of $C$. bifermentans were produced reduced their resistance to heat by up to 15 -fold and to $\mathrm{H}_{2} \mathrm{O}_{2}$ by up to 200 -fold (Fig. 2). Heating spores of $B$. subtilis at $85^{\circ} \mathrm{C}$ for $60 \mathrm{~min}$ in the presence or absence of $100 \mu \mathrm{M}-\mathrm{Cu}^{2+}$ produced the same number of survivors $(48 \%)$.

To produce colonies, spores must germinate and outgrow to form vegetative cells which are able to divide. We therefore examined the effect of heat with and without added $\mathrm{Cu}^{2+}$ on the ability of spores of $C$. bifermentans to germinate and outgrow. Spores heated at $70{ }^{\circ} \mathrm{C}$ after pre-incubation with $10 \mu \mathrm{M}-\mathrm{Cu}^{2+}$ (Fig. 3) or with various divalent metal ions at $100 \mu \mathrm{M}$ (Table 1) germinated more slowly with the 'Ala +' germination system than did spores heated in the absence of these ions. Spores incubated with $100 \mu \mathrm{M}-\mathrm{Cu}^{2+}$ at $1{ }^{\circ} \mathrm{C}$ outgrew at the same rate as spores incubated in the absence of $\mathrm{Cu}^{2+}$, but spores heated at $75^{\circ} \mathrm{C}$ with 
Table 1. Effect of divalent metal ions and heat on the germination rate of spores of C. bifermentans

Spores of $C$. bifermentans were incubated for $5 \mathrm{~min}$ at $37^{\circ} \mathrm{C}$ with the metal ion $(100 \mu \mathrm{M})$ indicated before centrifuging and washing. The spores were then resuspended in glass-distilled water and heated at $70^{\circ} \mathrm{C}$ for 0,30 or 60 min before germination with the 'Ala +' germination system.

\begin{tabular}{lccc} 
& \multicolumn{3}{c}{ Germination rate $\left(\% \mathrm{~min}^{-1}\right)$} \\
\cline { 3 - 4 } Metal ion & Unheated & $\overbrace{30 \mathrm{~min}}^{\text {After heating at }} \mathbf{7 0}^{\circ} \mathrm{C}$ for: \\
None & 91 & 94 & 73 min \\
$\mathrm{Cu}^{2+}$ & 101 & 16 & 3 \\
$\mathrm{Fe}^{2+}$ & 104 & 42 & 17 \\
$\mathrm{Zn}^{2+}$ & 97 & 59 & 34 \\
$\mathrm{Ni}^{2+}$ & 80 & 86 & 40 \\
$\mathrm{Co}^{2+}$ & 84 & 65 & 47 \\
$\mathrm{Mn}^{2+}$ & 87 & 67 & 52
\end{tabular}

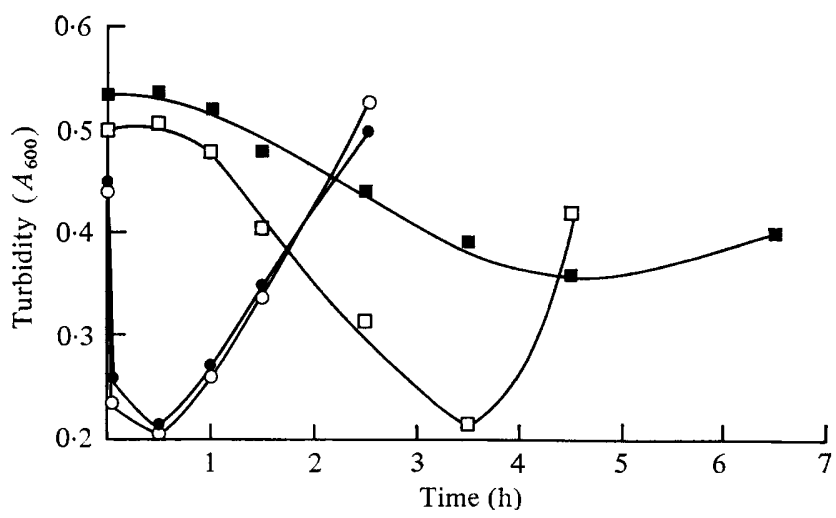

Fig. 4. Effect of heat and $\mathrm{Cu}^{2+}$ on the germination and outgrowth of spores of $C$. bifermentans. Spores were heated at $75^{\circ} \mathrm{C}$ for 10 min either with $(\square)$ or without $(\square) 100 \mu \mathrm{M}-\mathrm{Cu}^{2+}$, and the subsequent changes in turbidity during incubation in outgrowth medium were compared with those for unheated spores pre-incubated with (O) or without (O) $100 \mu \mathrm{M}-\mathrm{Cu}^{2+}$ at $1{ }^{\circ} \mathrm{C}$ for $60 \mathrm{~min}$.

$100 \mu \mathrm{M}-\mathrm{Cu}^{2+}$ germinated and outgrew more slowly than spores heated in the absence of added $\mathrm{Cu}^{2+}$ (Fig. 4).

Spores treated with urea/mercaptoethanol germinated in the presence of lysozyme, but this germination was completely inhibited by pre-incubation with $100 \mu \mathrm{M}-\mathrm{Cu}^{2+}$ and, to a lesser extent, by similar concentrations of other metal ions (Table 2). Pre-incubation with $100 \mu \mathrm{M}-\mathrm{Cu}^{2+}$ before treatment with urea/mercaptoethanol did not affect germination initiated by lysozyme.

\section{Uptake of $C u^{2+}$ by spores of $C$. bifermentans and B. subtilis}

Incubation of spores of $C$. bifermentans and B. subtilis with $100 \mu \mathrm{m}-\mathrm{Cu}^{2+}$ at $37^{\circ} \mathrm{C}$ resulted in rapid uptake of $\mathrm{Cu}^{2+}$, about $30 \%$ of which was lost during germination (Table 3). Since about $30 \%$ of the spore dry weight is lost during germination (Gould, 1969), this result might suggest binding of $\mathrm{Cu}^{2+}$ equally throughout the spore. Washing ungerminated spores with $0.03 \mathrm{M}-\mathrm{HCl}$ removed about $90 \%$ of the $\mathrm{Cu}^{2+}$, while treating them with urea/mercaptoethanol removed more than 97 and $99 \%$ of $\mathrm{Cu}^{2+}$ from ungerminated spores of $C$. bifermentans and B. subtilis, respectively. Washing spores with $\mathrm{HCl}$ may remove metal ions from the spore coat (Murrell \& Warth, 1965) and treatment with urea/mercaptoethanol ruptures 
Table 2. Effect of metal ions on germination with lysozyme of spores of C. bifermentans after treatment with urea/mercaptoethanol

Spores of C. bifermentans were treated with urea/mercaptoethanol before washing as described in Methods, incubating with the metal ion indicated, washing and incubating at $37^{\circ} \mathrm{C}$ with $100 \mu \mathrm{g}$ lysozyme $\mathrm{ml}^{-1}$ in the presence of $100 \mathrm{~mm}$-sodium phosphate buffer $\mathrm{pH} 7 \cdot 0$. The percentage of dark (germinated) spores was determined after 120 min by counting 100 spores using a phasecontrast microscope.

$\begin{array}{lc}\text { Metal ion }(\mu \mathrm{M}) & \begin{array}{r}\text { Phase-dark spores after } \\ 120 \mathrm{~min}(\%)\end{array} \\ \mathrm{None} & 82 \\ \mathrm{Cu}^{2+}(10) & 62 \\ \mathrm{Cu}^{2+}(20) & 31 \\ \mathrm{Cu}^{2+}(50) & 27 \\ \mathrm{Cu}^{2+}(100) & 4 \\ \mathrm{Zn}^{2+}(100) & 29 \\ \mathrm{Ni}^{2+}(100) & 40 \\ \mathrm{Fe}^{2+}(100) & 65 \\ \mathrm{Mn}^{2+}(100) & 75 \\ \mathrm{Co}^{2+}(100) & 82\end{array}$

Table 3. Uptake and subsequent loss of $\mathrm{Cu}^{2+}$ by spores of $C$. bifermentans and B. subtilis var. niger

Spores of $C$. bifermentans and B. subtilis var. niger were incubated at $37^{\circ} \mathrm{C}$ with $100 \mu \mathrm{M}-\mathrm{Cu}^{2+}$ and the $\mathrm{Cu}^{2+}$ present in the spores was measured at intervals as described in Methods. Spores pre-incubated at $37^{\circ} \mathrm{C}$ with $100 \mu \mathrm{M}-\mathrm{Cu}^{2+}$ for $20 \mathrm{~min}$ were also (a) germinated with the 'Ala +' system, $(b)$ washed by centrifugation with $0.03 \mathrm{M}-\mathrm{HCl}$ or $(c)$ treated with urea/mercaptoethanol, before the $\mathrm{Cu}^{2+}$ present was determined.

\section{Treatment}

Incubated with $100 \mu \mathrm{M}-\mathrm{Cu}^{2+}$ for (min):

0

1

5

10

90

Preincubated with $100 \mu \mathrm{M}-\mathrm{Cu}^{2+}$ then

(a) germinated or (b) washed with $0.03 \mathrm{M}-\mathrm{HCl}$

or $(c)$ treated with urea/mercaptoethanol
$\mathrm{Cu}^{2+}$ present in spores $\left(\mu \mathrm{g} \mathrm{g}^{-1}\right)$

$\begin{array}{ll}\text { C. bifermentans } & \begin{array}{l}\text { B. subtilis } \\ \text { var. niger }\end{array}\end{array}$

$\begin{array}{rr}185 & 265 \\ 7200 & 6900 \\ 7500 & 7500 \\ 8300 & 8100 \\ 12700 & 9040 \\ & \\ 9300 & 6050 \\ 1000 & 834 \\ 300 & 35\end{array}$

disulphide bonds in the spore coat (Gould \& Hitchins, 1963). It was probable, therefore, that $\mathrm{Cu}^{2+}$ was bound to the spore coat. However, examination of unstained electron micrographs of thin sections of spores showed that incubation with $100 \mu \mathrm{M}-\mathrm{Cu}^{2+}$ for $30 \mathrm{~min}$ at $37^{\circ} \mathrm{C}$, before washing with glass-distilled water, increased the electron density of the protoplasts of spores of $C$. bifermentans (Fig. $5 a, c$ ) but not those of spores of $B$. subtilis (Fig. $5 b, d)$. The protoplasts of spores of $C$. bifermentans also became more electron dense when sections were incubated with $100 \mu \mathrm{M}-\mathrm{Cu}^{2+}$ but those of $B$. subtilis did not, suggesting differences in the availability of binding sites for $\mathrm{Cu}^{2+}$.

Staining with uranyl acetate and lead acetate after sectioning increased the electron density of spores of both species. With spores of $C$. bifermentans the protoplasts increased in electron density, but those not pre-incubated with $\mathrm{Cu}^{2+}$ remained much less electron dense (compare Fig. $6 a$ and $6 b$ ), suggesting that the sites binding $\mathrm{Cu}^{2+}$ were different from those binding $\mathrm{UO}_{2}{ }^{2+}$ and $\mathrm{Pb}^{2+}$. With spores of $B$. subtilis the coats and cortices increased in electron density but the protoplasts remained unsiained.

Spores of $C$. bifermentans pre-incubated with $100 \mu \mathrm{M}-\mathrm{Fe}^{2+}$ showed electron-dense areas 

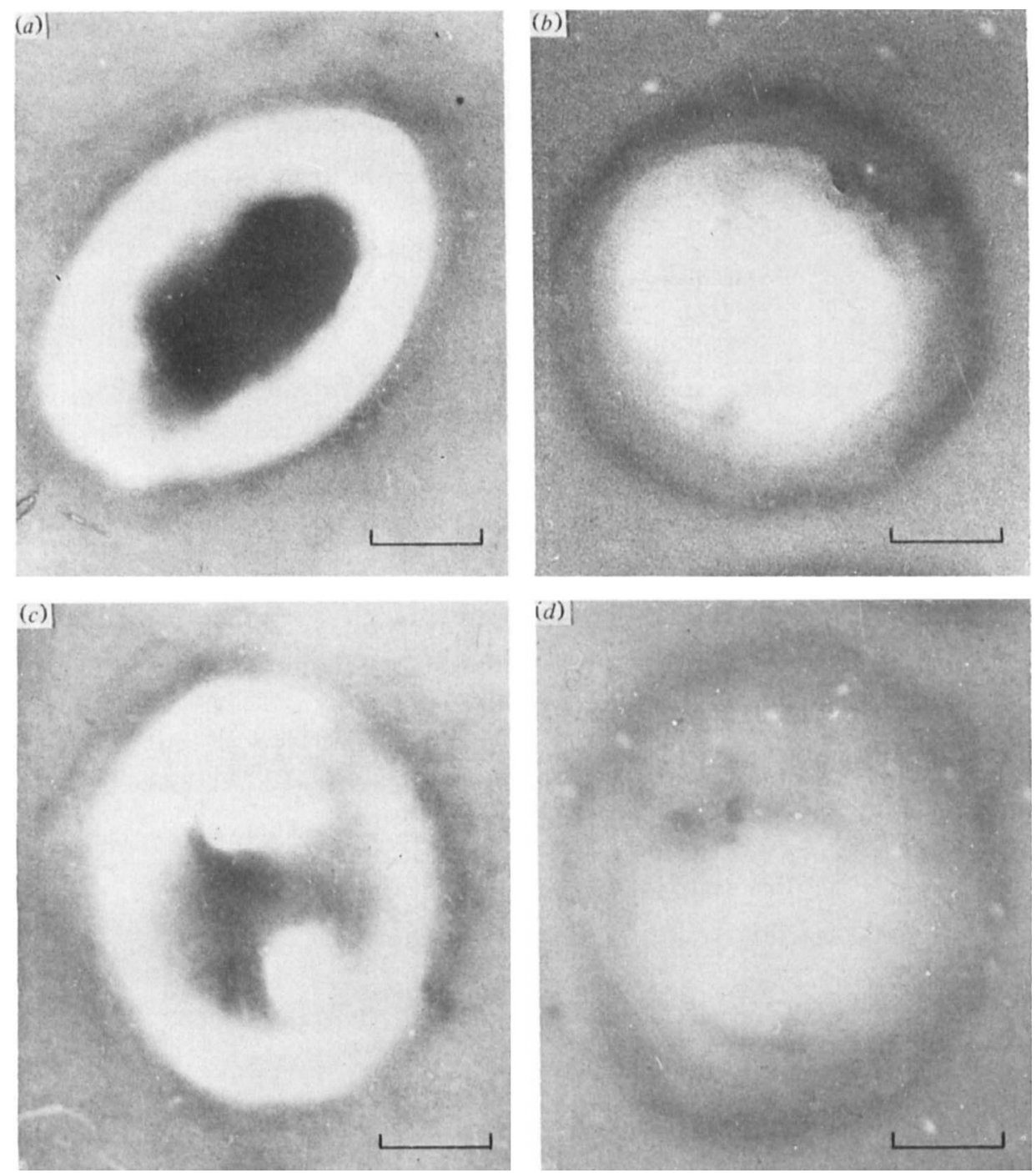

Fig. 5. Effect of $\mathrm{Cu}^{2+}$ on the ultrastructure of spores. Spores of $C$. bifermentans $(a, c)$ and $B$. subtilis $(b, d)$ were incubated for $30 \mathrm{~min}$ at $37^{\circ} \mathrm{C}$ with $(a, b)$ or without $(c, d) 100 \mu \mathrm{M}-\mathrm{Cu}^{2+}$ before washing with glass-distilled water, fixing with glutaraldehyde, embedding and sectioning as described in Methods. Bar markers represent 0.25 $\mu \mathrm{m}$.

around the exosporia (Fig. $7 a$ ) or, where these were damaged ot absent, around the coats (Fig. $7 b$ ). We have shown that the resistance of spores of C. bifermentans to $\mathrm{H}_{2} \mathrm{O}_{2}$ was only slightly decreased by the presence of $\mathrm{Fe}^{2+}$ (Bayliss \& Waites, 1976). It is probable, therefore, that only those metal ions like $\mathrm{Cu}^{2+}$ which bind to protoplasts are able to decrease spore resistance.

\section{DISCUSSION}

We have shown that $\mathrm{Cu}^{2+}$ markedly increased the lethal effect of $\mathrm{H}_{2} \mathrm{O}_{2}$ (Bayliss \& Waites, 1976) and of heat on spores of C. bifermentans but not on those of the other species examined, suggesting that certain sites in spores of $C$. bifermentans must be especially sensitive and/or accessible to $\mathrm{Cu}^{2+}$. Spores of $B$. subtilis and $C$. bifermentans took up $\mathrm{Cu}^{2+}$ at about the same rate but examination of unstained sections of spores by electron microscopy suggested that 

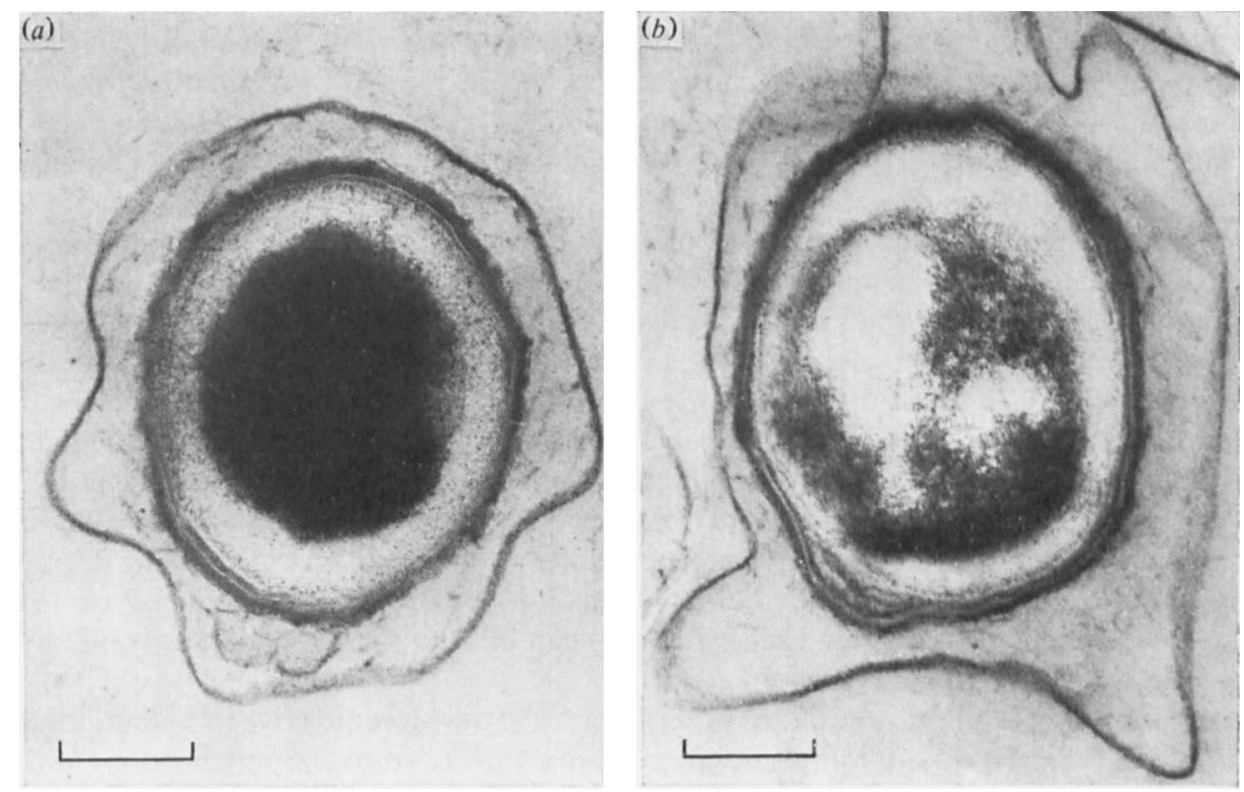

Fig. 6. Effect of $\mathrm{Cu}^{2+}$ on the ultrastructure of spores of $C$. bifermentans post-stained with uranyl acetate and lead acetate. Spores were incubated with $(a)$ or without $(b) 100 \mu \mathrm{M}-\mathrm{Cu}^{2+}$, as described for Fig. 5, before fixing, embedding and staining as described in Methods. Bar markers represent $0 \cdot 25 \mu \mathrm{m}$.
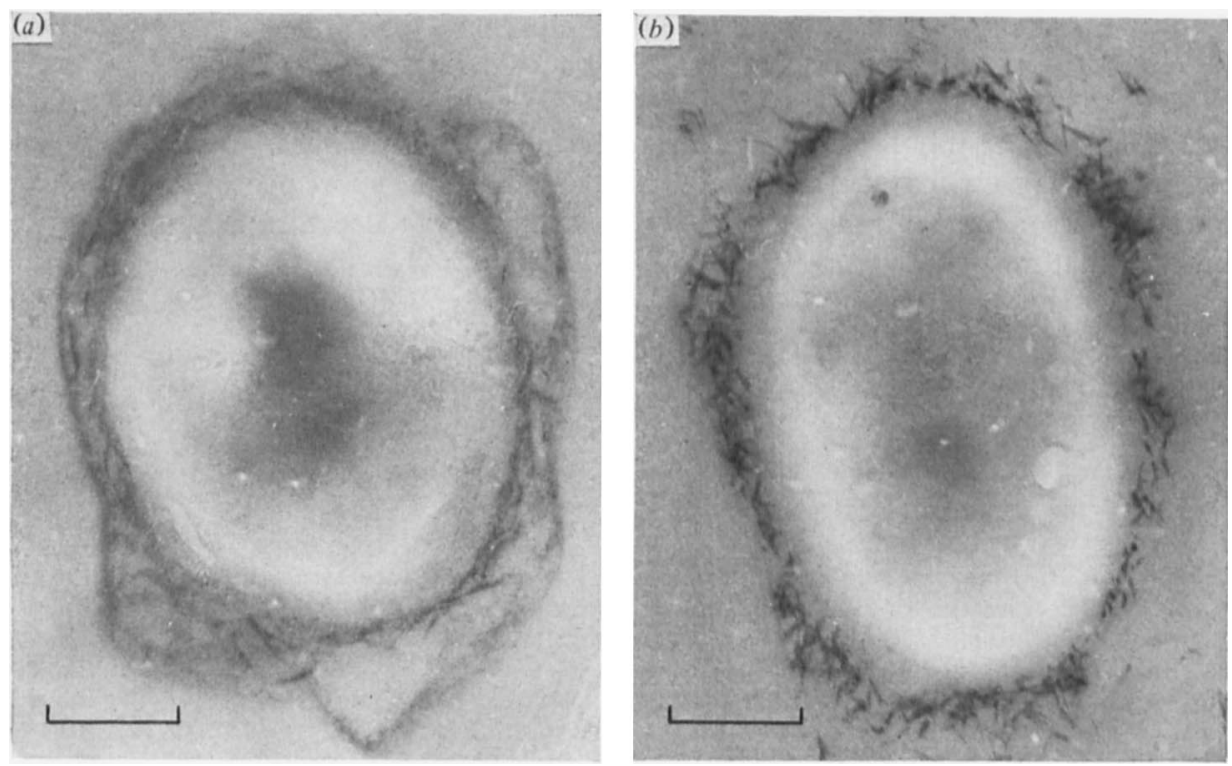

Fig. 7. Esct of $\mathrm{Fe}^{2+}$ on the ultrastructure of spores of $C$. bifermentans. Spores were incubated with $100 \mu \mathrm{M}-\mathrm{Fe}^{2+}$ before treating as described for Fig. 5. Bar markers represent $0.25 \mu \mathrm{m}$.

$\mathrm{Cu}^{2+}$ was bound by the protoplasts of spores of $C$. bifermentans but not those of spores of $B$. subtilis. Since most of the metabolism of an outgrowing spore will be in the protoplast, such differences are consistent with the greater lethal effect of $\mathrm{Cu}^{2+}$ on $C$. bifermentans. The greater resistance to $\mathrm{Cu}^{2+}$ and $\mathrm{H}_{2} \mathrm{O}_{2}$ of $B$. cereus, C. sporogenes PA 3679 and C. perfringens would suggest that, as with $B$. subtilis, $\mathrm{Cu}^{2+}$ was not bound to the protoplasts. The inability 
of $\mathrm{Cu}^{2+}$ to bind to protoplasts of spores of $B$. subtilis in section suggests that such differences depend more on the availability of metal-binding sites than on spore permeability. However, previous studies which have shown that metal ions can decrease the germination or viability of spores of other strains (Levinson \& Sevag, 1953; Krishna Murty \& Halvorson, 1957; Murakami, 1971; Wallen, 1976) suggest that metal ions may be able to bind to sensitive sites within spores of some species.

Examination of electron micrographs of thin sections of spores of C. bifermentans suggested that $\mathrm{Cu}^{2+}$ did not bind to the cortices. Beveridge \& Murray (1976) found that the ability of $\mathrm{Fe}^{2+}$ and $\mathrm{Cu}^{2+}$ to stain isolated walls of vegetative cells of $B$. subtilis was diminished after digestion by lysozyme, suggesting that peptidoglycan in the wall bound both $\mathrm{Fe}^{2+}$ and $\mathrm{Cu}^{2+}$. The peptidoglycan of the spore cortex is structurally similar, although not identical, to that of walls of vegetative cells (Tipper \& Gauthier, 1972) so that the cortex might be expected to bind $\mathrm{Cu}^{2+}$. If the cortex was highly expanded compared with the vegetative cell wall, as suggested by Gould \& Dring (1975), fewer $\mathrm{Cu}^{2+}$ binding sites/unit area would result in an apparently unstained cortex. Lysozyme initiates germination-like changes by degrading the spore cortex (Gould \& Hitchins, 1963). We have shown that $\mathrm{Cu}^{2+}$ prevented germination initiated by lysozyme, suggesting that metal ions can bind to the cortex but at too few sites to be detected by electron microscopy.

With spores of $C$. bifermentans, ions other than $\mathrm{Cu}^{2+}$ were less effective in potentiating the action of heat and $\mathrm{H}_{2} \mathrm{O}_{2}$ and inhibiting germination with lysozyme. Similarly, $\mathrm{Fe}^{2+}$ did not bind to spore protoplasts. Riemann (1961) and Albert (1950) showed that the stability constants of $\mathrm{Cu}$-dipicolinic acid, $\mathrm{Cu}$-EDTA and $\mathrm{Cu}$-glycine were higher than for other metal ions. In our work the order of effectiveness of metal ions varied; for inhibition of germination by lysozyme $\left(\mathrm{Cu}^{2+}>\mathrm{Zn}^{2+}>\mathrm{Ni}^{2+}>\mathrm{Fe}^{2+}>\mathrm{Mn}^{2+}>\mathrm{Co}^{2+}\right)$ the order was similar to the stability constants for metal-dipicolinic acid and metal-amino acid complexes $\left(\mathrm{Cu}^{2+}>\right.$ $\mathrm{Ni}^{2+}>\mathrm{Zn}^{2+}>\mathrm{Fe}^{2+}>\mathrm{Mn}^{2+}$ : Riemann, 1961; Albert, 1950) but those for potentiating the effect of $\mathrm{H}_{2} \mathrm{O}_{2}\left(\mathrm{Cu}^{2+}>\mathrm{Fe}^{2+}>\mathrm{Ni}^{2+}>\mathrm{Co}^{2+}>\mathrm{Zn}^{2+}\right.$ : Bayliss \& Waites, 1976) and heat $\left(\mathrm{Cu}^{2+}>\mathrm{Fe}^{2+}>\mathrm{Zn}^{2+}>\mathrm{Ni}^{2+}>\mathrm{Co}^{2+}>\mathrm{Mn}^{2+}\right)$ were different. Since the action of metal ions on $\mathrm{H}_{2} \mathrm{O}_{2}$ is probably to catalyse free radical production (King \& Gould, 1969), there is no reason to suggest that they bind to particular sites in the spore protoplast but it would be of interest to determine the sites at which $\mathrm{Cu}^{2+}$ acts to decrease heat resistance and inhibit germination by lysozyme.

We are grateful to Drs J. L. Peel and J. Payne for useful discussions and Mrs L. J. Wallwork for skilled technical assistance.

\section{REFERENCES}

Adams, D. M. (1973). Inactivation of Clostridium perfringens type A spores at ultrahigh temperatures. Applied Microbiology 26, 282-287.

AlberT, A. (1950). Quantitative studies of the avidity of naturally occurring substances for trace metals. I. Amino-acids having only two ionizing groups. Biochemical Journal 47, 531-538.

BaYliss, C. E. \& WaITES, W. M. (1976). The effect of hydrogen peroxide on spores of Clostridium bifermentans. Journal of General Microbiology 96, 401-407.

Beveridge, T. J. \& Murray, R. G. E. (1976). Uptake and retention of metals by cell walls of Bacillus subtilis. Journal of Bacteriology 127, 15021518.

Gordon, G. B., Miller, L. R. \& Bensch, K. G. (1963). Fixation of tissue culture cells for ultra- structural cytochemistry. Experimental Cell Research 31, 440-443.

Gould, G. W. (1969). Germination. In The Bacterial Spore, pp. 397-444. Edited by G. W. Gould \& A. Hurst. London: Academic Press.

Gould, G. W. \& DrING, G. J. (1975). Role of an expanded cortex in resistance of bacterial endospores. In Spores VI, pp. 541-546. Edited by P. Gerhardt, R. N. Costilow \& H. L. Sadoff, Washington, D.C.: American Society for Microbiology.

Gould, G. W. \& Hrtchins, A. D. (1963). Sensitization of bacterial spores to lysozyme and to hydrogen peroxide with agents which rupture disulphide bonds. Journal of General Microbiology 33, 413-423.

HILL, R. L. (1965). Hydrolysis of proteins. Advances in Protein Chemistry 20, 37-107. 
Hirsch, A. \& Grinsted, E. (1954). Methods for the growth and enumeration of anaerobic sporeformers from cheese, with observations on the effect of nisin. Journal of Dairy Research 21, 101110.

Kim, C. H., Cheney, R. \& Woodburn, M. (1967). Sporulation of Clostridium perfringens in a modified medium and selected foods. Applied Microbiology 15, 871-876.

KING, W. L. \& GoulD, G. W. (1969). Lysis of bacterial spores with hydrogen peroxide. Journal of Applied Bacteriology 32, 481-490.

Krishna MurTy, G. G. \& Halvorson, H. O. (1957). Effect of enzyme inhibitors on the germination and respiration of and growth from Bacillus cereus var. terminalis spores. Journal of Bacteriology 73, 230-234.

LeVinson, H. S. \& SevaG, M. G. (1953). Stimulation of germination and respiration of the spores of Bacillus megatherium by manganese and monovalent anions. Journal of General Physiology 36, 617-629.

MuraKaMI, H. (1971). Studies on the germination mechanism of Bacillus subtilis PC 219 spores. II. Effect of transition metal ions on the darkening of germinating spores. Nippon nogei kagaku kaishi 45, 381-385.

Murrell, W. G. \& Warth, A. D. (1965). Composition and heat resistance of bacterial spores. In Spores III, pp. 1-24. Edited by L. L. Campbell \& H. O. Halvorson. Ann Arbor, Michigan: American Society for Microbiology.

RIEMANN, H. (1961). Germination of bacterial spores with chelators with special reference to the calcium- dipicolinic acid germination system. Ph.D. thesis, Slagteriernes Forskningsinstitut, Denmark.

TiPPER, D. J. \& GAUTHIER, J. J. (1972). Structure of the bacterial endospore. In Spores $V$, pp. 3-12. Edited by H. O. Halvorson, R. Hanson \& L. L. Campbell. Washington, D. C.: American Society for Microbiology.

WAITES, W. M. \& WyatT, L. R. (1971). Germination of spores of Clostridium bifermentans by certain amino acids, lactate and pyruvate in the presence of sodium or potassium ions. Journal of General Microbiology 67, 215-222.

Waites, W. M. \& WyatT, L. R. (1974). The outgrowth of spores of Clostridium bifermentans. Journal of General Microbiology 84, 235-244.

Wartes, W. M., WyatT, L. R. \& ARTHUR, B. (1972). Effect of alkali treatment on the germination and morphology of spores of Clostridium bifermentans. In Spores $V$, pp. 430-436. Edited by H. O. Halvorson, R. Hanson \& L. L. Campbell. Washington, D.C.: American Society for Microbiology. WALlEN, S. E. (1976). Sporicidal action of hydrogen peroxide. Ph.D. thesis, University of Nebraska, Lincoln, Nebraska, U.S.A.

Wyatt, L. R. \& WaItes, W. M. (1974). The effect of sodium hydroxide or dithiothreitol-urea on spores of germination mutants of Clostridium bifermentans. Journal of General Microbiology 84, 391-394.

Wyatt, L. R. \& Waites, W. M. (1975). The effect of chlorine on spores of Clostridium bifermentans, Bacillus subtilis and Bacillus cereus. Journal of General Microbiology 89, 337-344. 